\title{
Changes in Water Resources of Polish Lakes as Influenced by Natural and Anthropogenic Factors
}

\author{
Adam Choiński ${ }^{1}$, Mariusz Ptak ${ }^{1}$, Agnieszka E. Lawniczak ${ }^{2 *}$ \\ 'Institute of Physical Geography and Environmental Planning, Adam Mickiewicz University, \\ Dzięgielowa 27, 61-680 Poznań, Poland \\ 2Poznan University of Life Sciences, Department of Ecology and Environmental Protection, \\ Piątkowska St. 94C, 60-649 Poznań, Poland
}

Received: 23 March 2016

Accepted: 26 April 2016

\begin{abstract}
Processes of lake shrinkage as a result of the action of natural and anthropogenic factors in recent decades have been considerably accelerated. On the other hand, lake capacities may have increased as a consequence of damming. These changes are typically analyzed in relation to changes in lake area, while horizontal and vertical components are excluded. The aim of this study was to assess changes in morphometry in several lakes in central western Poland and to determine changes in water resources in selected lakes as a result of changes in their morphometry. These changes were analyzed based on archival data concerning the area and capacity of lake basins, collected from studies prepared by the Institute of Inland Fisheries in the early 1960s and current bathymetric studies. These investigations showed that within approx. 50 years a considerable decrease was recorded in the area of the analyzed group of lakes, amounting to $14.8 \%$ (i.e., 172.6 ha). As a result of changes in the area and shallowing of lakes, the water resources stored in lakes decreased by a total of $7.7 \%$, which amounts to 3.6 million $\mathrm{m}^{3}$. Referring to the factors determining the above-mentioned transformations, it was found that both climatic and anthropogenic conditions were disadvantageous. While in the study period no trends were observed for changes in precipitation, a significant increase in temperature was found, thus contributing to increased evaporation. This situation was compounded by human activity connected with land reclamation operations or agricultural activity.
\end{abstract}

Keywords: lake disappearance, bathymetry changes, lake shallowing

\section{Introduction}

Northeastern central Europe is characterized by a considerable number of lakes [1]. These lakes play an important role in the preservation of water resources and biodiversity, while they also are significant for economic activity [2]. Their occurrence is connected with the limits of the last Weichselian glaciation. In the case of Poland there are more than 7,000 natural lakes with an area of min. 1 ha [3]. They are located mainly within three large lake districts: Pomerania, Wielkopolsko-Kujawskie, and Masuria.

*e-mail: lawnic@up.poznan.pl 
Postglacial lakes have been evolving since they were formed, which in the end results in their shrinkage. The rates of these processes vary and generally depend on morphometric characteristics of the lakes, the size and character of catchment use, climatic conditions, etc. [4-7]. The process of lake shrinkage may be the result of a lake basin filling with deposits and fluctuations of water levels. In the latter aspect a particular role is played by human activity, which through, e.g., land reclamation operations in the catchment may have a marked effect on fluctuations in water tables and their continuous lowering. In extreme cases we have observed a drastic reduction of their area or complete discharge of water from lakes [4-5].

Data obtained so far, based on the analysis of changes in the area, indicate that the mean forecasted age of lakes in Poland is approx. 2000 years [8]. Thus it is a short period in the geological scale. Moreover, it needs to be remembered that lake basins, being three-dimensional objects, are also subject to the process of lake shrinkage connected with their shallowing. In view of several functions served by lakes in the natural environment - both in relation to its natural elements (water cycle, microclimate, biodiversity, etc.) as well as artificial ones related with human life (agricultural irrigation, industry, tourism, etc.) - it is obvious that lakes should function in the environment for the longest possible period, serving the above (and other) roles to the greatest possible extent. A significant problem is connected with water deficits observed in different regions of the world [9-11], and lakes may constitute considerable reservoirs of readily available water, in contrast, e.g., to underground waters. Poland is a country with the least amount of water resources in Europe [12] comparable to those of Egypt. At least for this reason it is essential to have detailed information on water resources deposited in lakes and the changes affecting them.

The aim of this study was to 1) determine in a comprehensive manner the changes in lakes, covering the horizontal and vertical components connected with their contemporary evolution and 2) to determine changes in water resources of selected lakes in the Wielkopolska region as a result of changes in their morphometry.

\section{Material and Methods}

This paper presents an analysis of changes in the area and capacity of 18 lakes located in west-central Poland (Fig. 1). The location of lakes to a considerable extent overlaps with the area of the lowest water resources in Poland. Low precipitation and relatively high air temperature result in a situation when the mean specific discharge in many regions is as low as $2-2.5 \mathrm{dm}^{3} \cdot \mathrm{km}^{2} \cdot \mathrm{s}^{-1}$ [13]. A key aspect in the selection of the lakes was related to the bathymetric studies by the Institute of Inland Fisheries in Olsztyn (IRŚ) prepared in the 1960s. The analyses of changes in area of the lakes was based on data given in the bathymetric charts of the institute and on 1:50,000 hydrographic maps of Poland from the early $21^{\text {st }}$ century.

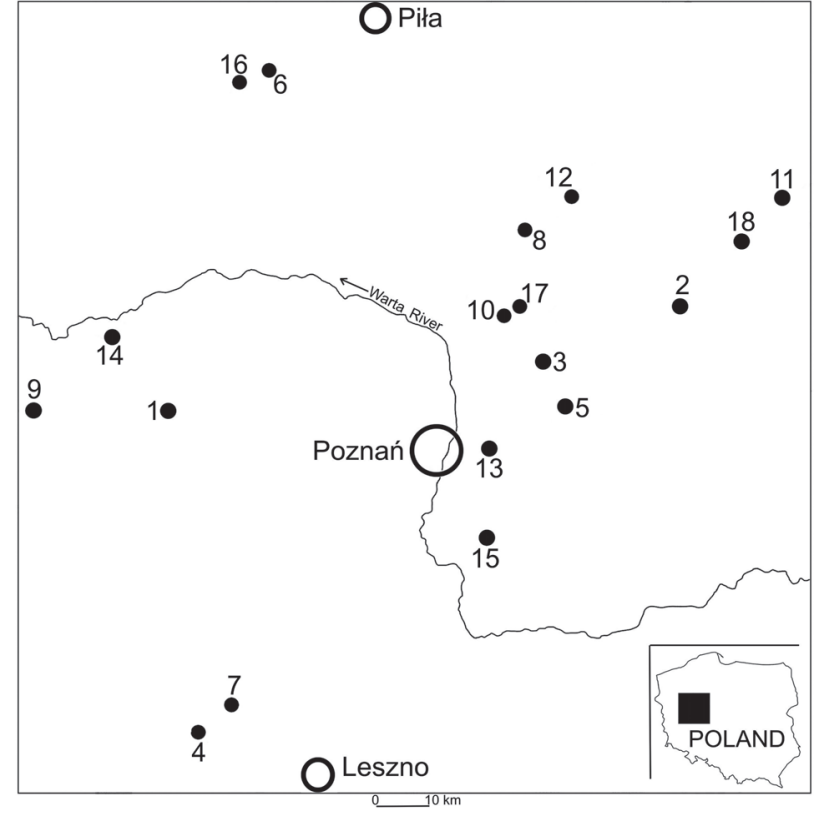

Fig. 1. Locations of analyzed lakes: 1 - Konińskie, 2 - Mielno, 3 - Turosławskie, 4 - Linicjusz, 5 - Biezdruchowo, 6 - Sarcze, 7 - Wielkie, 8 - Łęgowskie, 9 - Pszczewskie, 10 - Włókna, 11 - Kierzkowskie, 12 - Łeknieńskie, 13 - Swarzędzkie, 14 - Ławickie, 15 - Skrzynka, 16 - Straduń, 17 - Maciejak, and 18 - Gąsawskie.

In the determination of bathymetry for the analyzed lakes we applied the method presented by Choiński et al. [14].

Measurements were taken in 2013 and 2014 using a Garmin Fishfinder 100 sonar and a GPS Garmin GPS 12

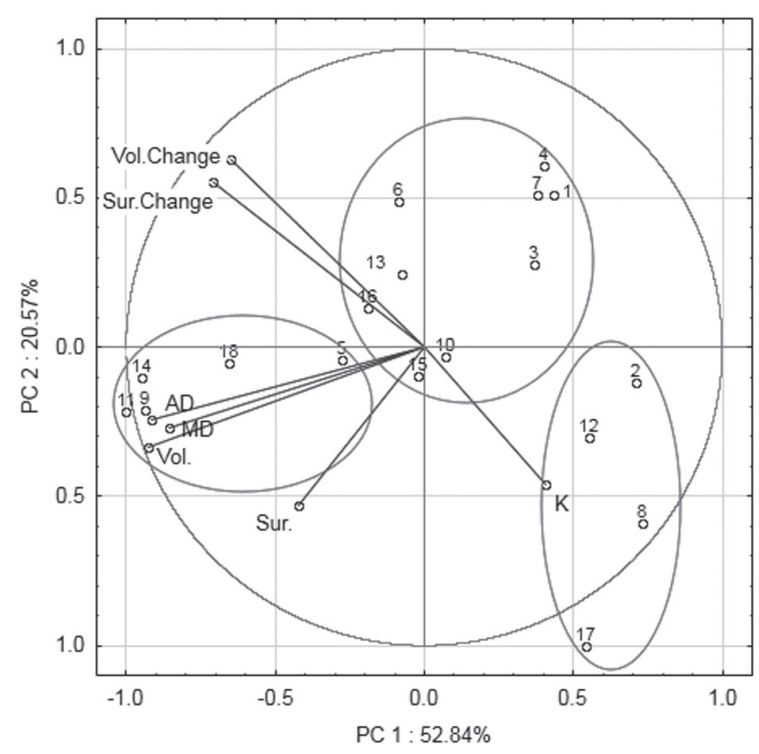

Fig. 2. Distribution of the analyzed lakes in the system of the first two principal components (PC1 and PC2) based on morphological parameters.

Abbreviations: Vol. Change - lake volume changes, Sur. Change - lake area changes, $\mathrm{AD}$ - average depth, $\mathrm{MD}$ - maximum depth, Vol. - volume, Sur. - lake area, K - shoreline development index, 1-18 - studied lakes. 
Table 1. Selected morphometric parameters of analyzed lakes in two studied time periods.

\begin{tabular}{|c|c|c|c|c|c|c|c|}
\hline \multirow{3}{*}{$\begin{array}{l}\text { Lake } \\
\text { number }\end{array}$} & \multirow{3}{*}{ Lake name } & \multicolumn{3}{|c|}{$1950 \mathrm{~s} / 1960 \mathrm{~s}$} & \multicolumn{3}{|c|}{ Early $21^{\text {st }}$ century } \\
\hline & & Surface & Volume & Average depth & Surface* & Volume & Average depth \\
\hline & & [ha] & {$\left[\mathrm{mln} \mathrm{m}^{3}\right]$} & {$[\mathrm{m}]$} & [ha] & {$\left[\mathrm{mln} \mathrm{m}^{3}\right]$} & {$[\mathrm{m}]$} \\
\hline 1 & Konińskie & 24.2 & 0.4 & 1.7 & 23.0 & 0.3 & 1.3 \\
\hline 2 & Mielno & 26.1 & 0.6 & 2.3 & 18.1 & 0.4 & 2.2 \\
\hline 3 & Turosławskie & 32.9 & 0.8 & 2.6 & 25.7 & 0.7 & 2.7 \\
\hline 4 & Linicjusz & 37.5 & 0.4 & 1.3 & 30.0 & 0.4 & 1.3 \\
\hline 5 & Biezdruchowo & 48.8 & 2.8 & 5.7 & 37.8 & 2.6 & 6.9 \\
\hline 6 & Sarcze & 51.1 & 1.9 & 3.7 & 48.9 & 1.9 & 3.9 \\
\hline 7 & Wielkie & 51.2 & 0.6 & 1.3 & 40.0 & 0.5 & 1.3 \\
\hline 8 & Łęgowskie & 68.4 & 1.2 & 1.8 & 43.5 & 0.8 & 1.8 \\
\hline 9 & Pszczewskie & 68.7 & 6.5 & 9.5 & 61.6 & 5.7 & 9.3 \\
\hline 10 & Włókna & 74.4 & 2.4 & 3.2 & 60.7 & 2.2 & 3.6 \\
\hline 11 & Kierzkowskie & 77.3 & 6.1 & 8.0 & 72.2 & 5.8 & 8.0 \\
\hline 12 & Łeknieńskie & 85.2 & 1.3 & 1.6 & 56.9 & 0.9 & 1.6 \\
\hline 13 & Swarzędzkie & 90.0 & 2.1 & 2.3 & 81.4 & 2.3 & 2.8 \\
\hline 14 & Ławickie & 90.1 & 6.5 & 7.3 & 82.8 & 6.4 & 7.7 \\
\hline 15 & Skrzynka & 91.5 & 3.1 & 3.4 & 72.1 & 2.6 & 3.6 \\
\hline 16 & Straduń & 96.7 & 3.0 & 3.2 & 90.5 & 2.8 & 3.1 \\
\hline 17 & Maciejak & 59.0 & 1.7 & 2.7 & 61.2 & 1.7 & 2.8 \\
\hline 18 & Gąsawskie & 99.0 & 5.7 & 5.8 & 93.1 & 5.4 & 5.8 \\
\hline & Average & 1172.1 & 47.1 & 3.7 & 999.5 & 43.4 & 3.9 \\
\hline
\end{tabular}

*area of lakes by Czarnecka et al. [13]

receiver. In view of the fact that the Institute was sounding the lake bottoms using a sounding line in order to eliminate the measurement error resulting from the application of a different methodology (echo sounder), results were verified by comparing echo sounder measurements with the results provided by the sounding line. Lake capacity was determined according to Penck's method, in which the lake basin is equivalent to a set of truncated pyramids closed with a cone.

Principal component analysis (PCA) was employed to investigate differences between lakes based on morphological parameters. All statistical analyses were performed using Statistica (StatSoft, Poland) software.

\section{Results}

The analysis of 18 lakes in Wielkopolska showed that their shrinkage rates vary. Based on morphological parameters and the rate of disappearance in the PCA diagram, lakes were classified into three groups (Fig. 2). The first two factors identified $73.41 \%$ total variation. The first group comprised four lakes characterized by the greatest change in capacity and area, i.e., Lakes
Mielno, Łęgowskie, Łeknińskie, and Maciejak. The other distinguished group with the greatest capacity or depth included five lakes: Biezdruchowo, Miejskie, Kierzkowskie, Ławickie, and Gąsawskie. The other lakes with a varied overgrowth rate or shallowing rate as well as differing in morphometric parameters comprised the other group.

Data concerning changes in morphometry of the investigated lakes in relation to the main parameters are given in Table 1. In the analyzed period of approx. 50 years we have been observing a considerable transformation of lake ecosystems. We need to stress a considerable reduction of lake area by a total area of 172.6 ha, which constitutes a decrease in relation to the initial status by as much as $14.8 \%$. The greatest area shrinkage was found in Lake Łęgowskie (36.4\%) (Fig. 3). In turn, the smallest shrinkage was recorded in Lake Sarcze (4.3\%).

As a result of the reduced area and the simultaneous process of shallowing, a decrease was observed in water resources stored in the analyzed lakes. Jointly for all lakes we observed a reduction of water resources by 3.6 million $\mathrm{m}^{3}$, which constitutes $7.7 \%$ decreased capacity in relation to the 1950 s. For comparison, the total water resources of lakes in Poland amounts to ca. $20 \mathrm{~km}^{3}$. The greatest 


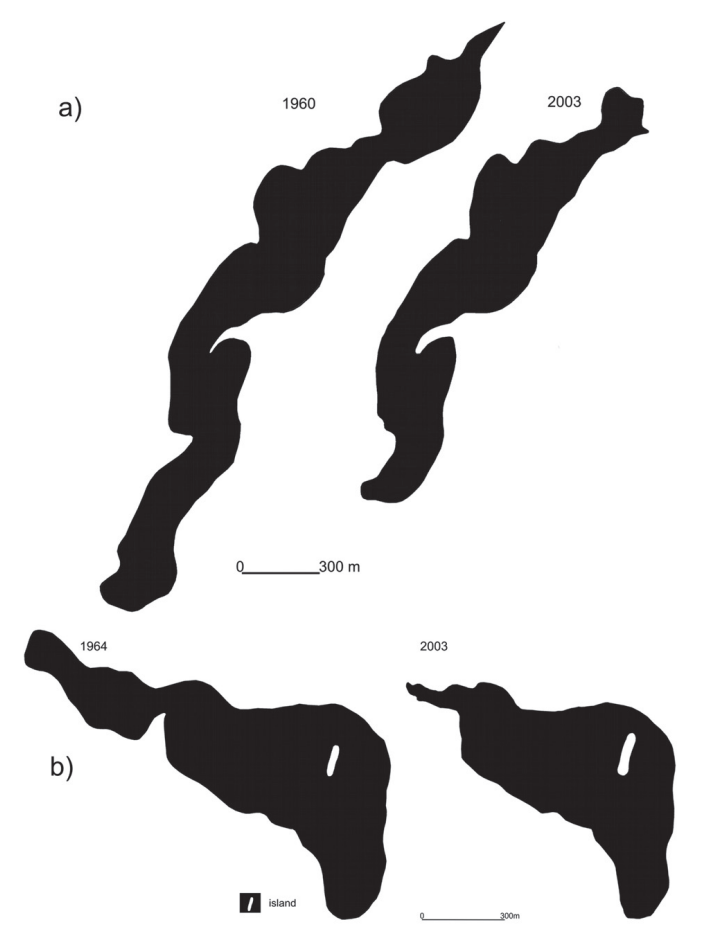

Fig. 3. Selected examples of changes in lake area: a) Lake Łęgowskie, b) Lake Biezdruchowo.

depletion of water resources was recorded for Lakes Łęgowskie and Mielno (Fig. 4), which in both cases was as much as 33\%. Mean depth (calculated as a ratio of lake capacity to its area) specified jointly for all lakes increased by $0.2 \mathrm{~m}$, which is a result of the considerable reduction of their area.

The greatest changes in bathymetry of lakes were observed within the shallowest isobaths. Analyses showed a shift in individual isobaths toward the centre of lakes. In the case of Lake Mielno we may consider the narrowing between the two basins - where the continuity of the 1 $\mathrm{m}$ isobath is broken - as the characteristic site. In turn, in the case of Lake Biezdruchowo the characteristic site may the identified as the area of an island whose growth has contributed to considerable changes in the distribution of isobaths. In both cases the predominant volume of shallowing was approx. $<0.5 \mathrm{~m}$.

\section{Discussion}

Problems of contemporary morphometric changes in lakes are extensively investigated in different parts of the world, comprising both analyses of their area [1520] and bathymetry [21-25]. The rates and scales of these transformations vary. Comparable findings to those reported in this study (e.g., due to climatic conditions and the scale of anthropopressure) were given in earlier studies concerning lakes in Poland, conducted in various periods and for a varied numbers of water bodies. They may be referred both to changes in area [26-30] and bathymetry [31-35]. In both cases they are consistent and thus they

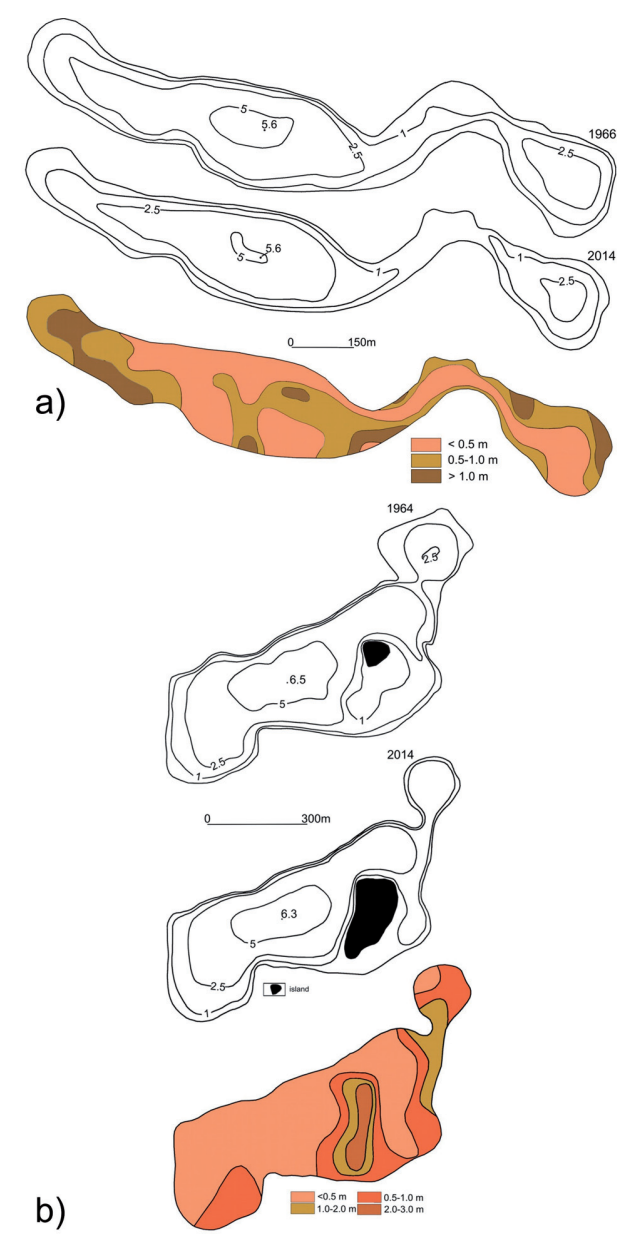

Fig. 4. Changes in bathymetry and shallowing of lakes: a) Mielno, b) Turostowo.

confirm that we are observing successive reductions of lake area and depletion of water resources.

In spatial terms (i.e., referring to the region or individual catchments) it is frequently difficult to identify factors responsible for changes in lake area and bathymetry. It is essential to definitely specify processes influencing fluctuations of water levels. Bonacci et al. [36], when referring to changes in water levels in Lake Dojran, stressed that it is not easy to specify what determines them, whether it is climatic factors or whether they are caused by human activity. This statement may be considered universal in many other cases. Moreover, monitoring sites of hydrological conditions located in the vicinity of drainage networks [37] additionally hinders determining causes of water level changes.

Analyses of changes in climatic conditions for the Poznań weather station (located in the central part of the analyzed area) in the period investigated in this study are presented in Fig. 5 [based on 38-39].

We see from the graphs presented above that over the entire multiannual period no significant trend was observed for changes in precipitation, and that a marked increase in air temperature was recorded. This increase at the Poznan station is consistent with the course of air temperature in other regions of Poland, and it is directly 

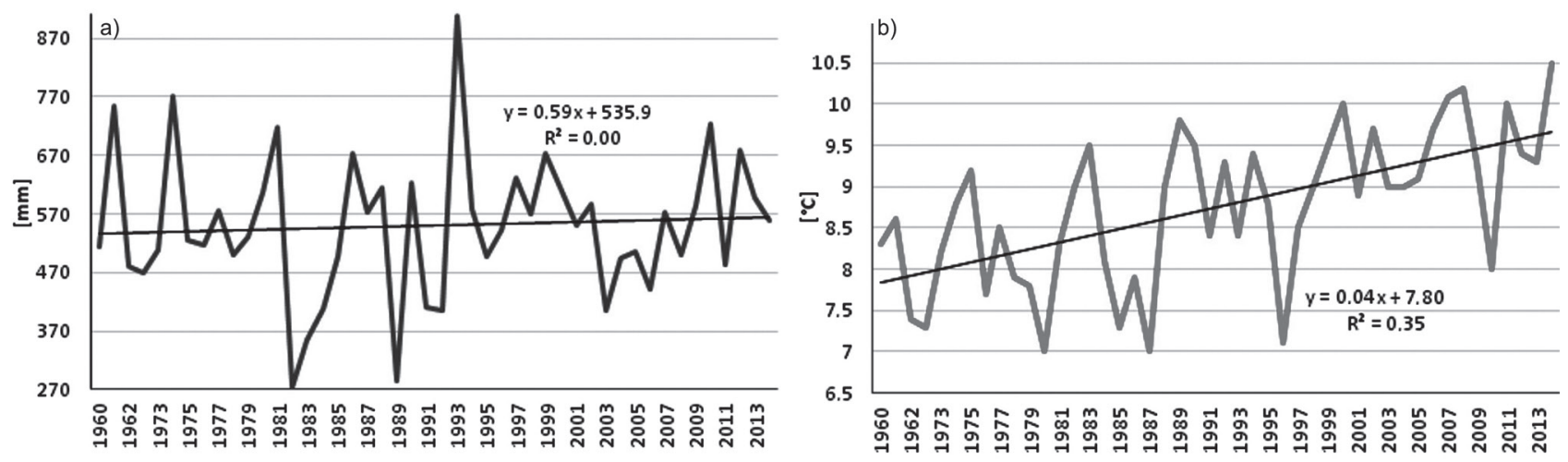

Fig. 5. Fluctuations in precipitation a) and air temperature b) for the Poznań weather station in 1960-2014 [based on 38-39].

reflected in the elevation of lake water temperatures [40]. Such a situation affects changes in the components of the water balance of the lakes. Kędziora [41] stated that for Wielkopolska (i.e., the area where most lakes in this study are located) in the years 1996-2006 evaporation from the water surface increased from 600 to $1,000 \mathrm{~mm}$. In turn, Chmal [42], when investigating evaporation from the water surface of Lake Sławskie (located approx. $20 \mathrm{~km}$ from analyzed lakes Linicjusz and Wielkie) in 2007 stated that it was greatest in June and amounted to $114.3 \mathrm{~mm}$. In the same month the precipitation total for Leszno station (approx. $40 \mathrm{~km}$ from Lake Sławskie) was $47.5 \mathrm{~mm}$ (en.tutiempo.net). Thus the deficit was considerable and amounted to almost $67 \mathrm{~mm}$.

Another element contributing to changes in water levels and thus changes in lake area is connected with human activity. Water bodies whose catchments have been affected by drainage operations differ markedly from neighboring lakes in terms of transformation processes [43-44]. The greatest intensity of large-scale drainage operations in Poland was observed in the 19th century. As a result, water levels dropped considerably in many lakes (also in the study area), occasionally leading to their

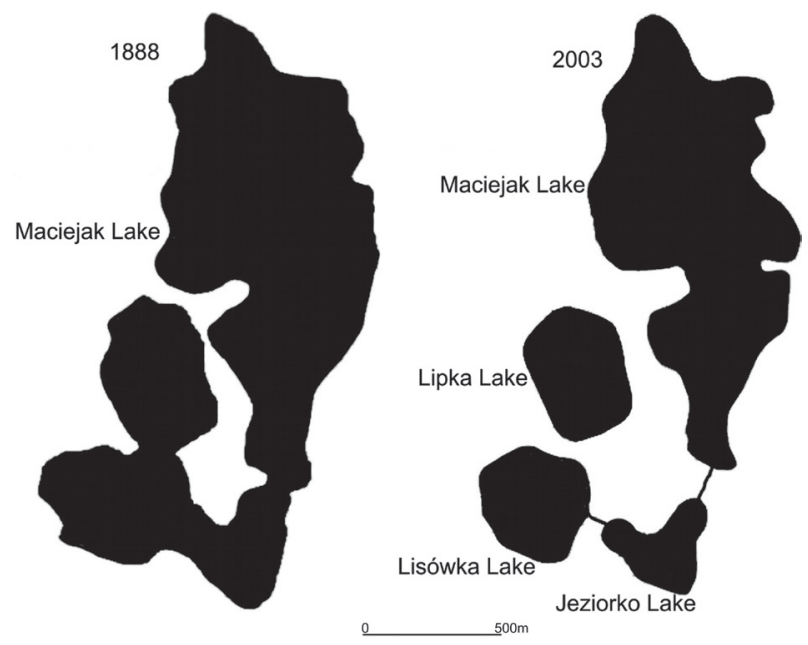

Fig. 6. Division of Lake Maciejak into several water bodies in the period 1888-2003. complete drainage [7]. Among the analyzed lakes, over the course of decades a marked decrease in water levels (amounting to $1.1 \mathrm{~m}$ ) was recorded in Lake Maciejak (Fig. $6)$.

Optimal assumptions for hydroengineering works should ensure regulation of water relations so that it may be possible to discharge waters in the case of their excess and facilitate their retention during shortages. In the case of lakes, dual control may be executed thanks to the damming infrastructure located on the watercourses flowing out of these lakes (weirs, gates). In the set of lakes analyzed in this study there are several on which such a practice was applied, e.g., lakes Łęgowskie, Konińskie, Straduń, and Swarzędzkie.

The effect of hydroengineering structures on stopping the decrease in lake area and water resources in the above-mentioned cases may not be definitely evaluated. Despite the potential to maintain the assumed water level, area decreased in all lakes. Moreover, except for Lake Swarzędzkie (Fig. 7), a reduction of water resources was also recorded.

Situations in which the area was also reduced (apart from the potential stabilization of water levels) need to be associated with their overgrowth. This process is relatively common [45-46] and, as indicated by the situations described in this study, it affects even those lakes in which the water level is regulated artificially. An example of vegetation succession is presented in Fig. 8.

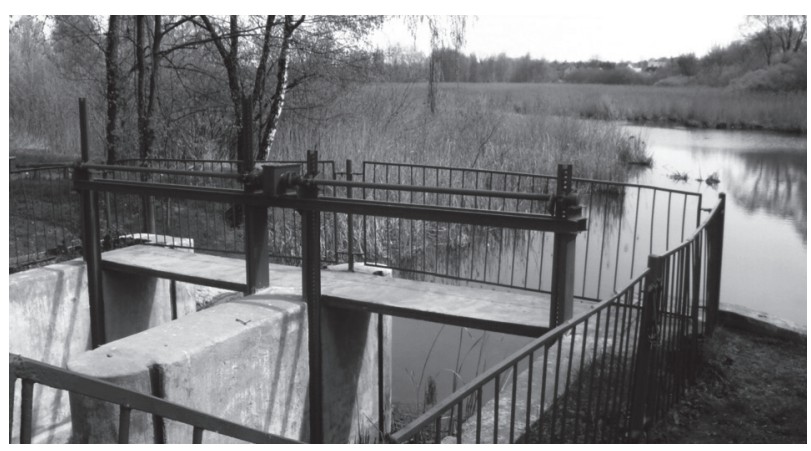

Fig. 7. A weir in Lake Swarzędzkie; in the background is considerable vegetation succession. 


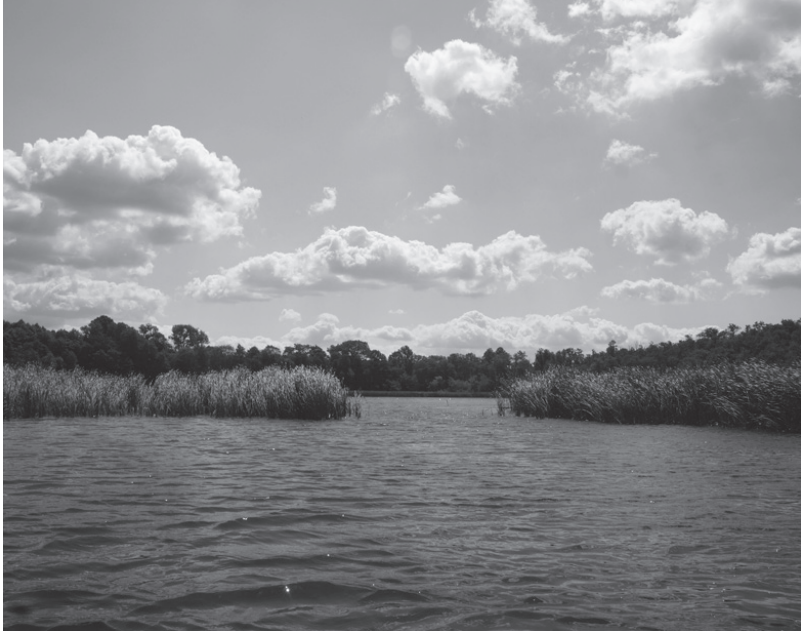

Fig. 8. The overgrowing Lake Mielno.

The scale and rate of lake overgrowth, next to direct human interference, is connected with the lowering of water levels in lakes (i.e., when water damming on a larger scale is rather exceptional), and thus the exposure of the shallower sections of the littoral zone has been considerably accelerated by the inflow of biogens from agricultural sources [47]. This manifestation of the human impact on lake ecosystems was limited, e.g., at Poland's accession to the European Union. The need to standardize legal regulations in Poland to conform to EU requirements (e.g., the Nitrate Directive) was connected with the reduction of the influx of nitrogen and phosphorus compounds, although obviously it has not eliminated them completely. Moreover, the growth of aquatic vegetation may be stimulated by the secondary supply of lakes, where, e.g., as a result of resuspension of deposits, biogens are again introduced to the pelagic zone and this contributes to the deterioration of the trophic state. Internal supply is frequently the main component of the presence of nutrients in water [48-50]. Due to the deforestation of central Poland dating back several centuries, in most cases the analyzed lakes are located in catchments with predominant agricultural areas with intensive farming systems. Even lakes situated in areas legally protected in many cases may be degraded. Pasztaleniec and Kutyła [51], when analyzing 92 lakes located in national and landscape parks, stated that only $50 \%$ of them had at least good ecological status, while the others were classified as moderate, poor, or bad.

Other intermediate forms of human impact on the functioning of lakes are also connected with human activity in the catchment and they are manifested, e.g., in the lowering of groundwater levels. A complicated problem related both to the indirect human impact together with the accompanying adverse changes in natural conditions was presented by Przybyłek and Nowak [52]. Those authors found that both mining-related drainage and adverse climatic conditions are responsible for the lowering of water levels in lakes in central Poland (the Gnieźnieńskie Lake District).

\section{Conclusions}

The analysis of the area and bathymetry presented in this paper for the group of around a dozen lakes located in west central Poland indicates that in a period of approximately 50 years we have observed their considerable transformation, most noticeably in the marked decrease in their area and water resources stored in lake basins. The achieved results show a $1.7 \%$ reduction of lake surfaces and a nearly two times lower reduction of water resources, amounting to $7.9 \%$. These results indicate that the reduction of lake surfaces is more significant than lake shallowing. These changes, due to the functions served by lakes in the natural environment, need to be considered undesirable. A particularly important role is played by the successive decrease in the water storage capacity of lakes. It is particularly crucial in view of the recently observed and increasing hydrological and extreme weather processes (floods, droughts). Lakes, due to their high retention potential, have a stabilizing effect in such situations in their catchments.

When discussing changes in lake area and bathymetry we need to be aware that they are a natural element of their evolution. In the case of analyzed lakes this evolution is accelerated by human activity and climate change. However, it is nevertheless difficult to identify causes for morphometric changes taking place in lakes. An exception in this case is provided by lakes subjected to the direct process of water regulation, which clearly and definitely indicates causes for changes in their area and bathymetry.

The scale of changes in bathymetry due to a lack of comparable data for a larger set of lakes is still insufficiently clarified. Lake sounding as a result of its labor intensity is most typically undertaken on single lakes or a set of several water bodies. These data need to be considered valuable, as thanks to them it is possible to determine changes in lakewater resources in Poland, and as a result identify current water resources in our country.

\section{Acknowledgements}

This work has been financed by the National Science Centre, project No. UMO-2011/03/B/NZ9/03774, titled "The impact of human pressure on overgrowing and shallowing of lakes."

\section{References}

1. HEINE I., STÜVE P., KLEINSCHMIT B., ITZEROTT S. Reconstruction of lake level changes of groundwater-fed lakes in northeastern Germany using rapid eye time series. Water 7, 2015.

2. KAISER K., KOCH P. J., MAUERSBERGER R., STÜVE P., DREIBRODT J., BENS O. Detection and attribution of lake level dynamics in Northeastern central Europe in recent decade. Reg Environ Change 14, 4, 2014.

3. CHOIŃSKI A. Catalogue of Polish Lakes. UAM Science Publishing, Poznań, 2006 [In Polish]. 
4. GAYBULLAEV B., CHEN S.- C., KUO Y. - M. Large-scale desiccation of the Aral Sea due to over-exploitation after 1960. J MT SCI 9, 4, 2012.

5. PTAK M., CHOIŃSKI A., STRZELCZAK A., TARGOSZ A. Disappearance of Lake Jelenino since the end of the XVIII century as an effect of anthropogenic transformations of the natural environment, Pol J Environ Stud 22, 1, 2013.

6. PIASECKI A., SKOWRON R. Changing the geometry of basins and water resources of Lakes Gopło and Ostrowskie under the influence of anthropopressure. Limnol. Rev. 14, $1,2014$.

7. CHOIŃSKI A., PTAK M., STRZELCZAK A. Examples of Lake disappearance as an effect of reclamation Works in Poland. Limnol. Rev. 12, 4, 2012.

8. CHOIŃSKI A. Physical limnology of Poland. UAM Science Publishing, Poznań, 2007 [In Polish].

9. MISSIMER T. M., DANSER P. A., AMY G., PANKRATZ T. Water crisis: the metropolitan Atlanta, Georgia, regional water supply conflict. Water Policy 16, 4, 2014.

10. GORJIAN S., GHOBADIAN B. Solar desalination: A sustainable solution to water crisis in Iran. Renew Sust Energ Rev 48, 1, 2015.

11. TARGA M. S., BATISTA G. T. Benefits and legacy of the water crisis in Brazil. Revista Ambiente e Agua 10, 2, 2015.

12. KOWALCZAK P., FARAT R., KEPIŃSKA-KASPRZAK M., KUŹNICKA M., MAGER P. Hierarchy of aerial small water retention need. Materiały badawcze, seria: Gospodarka Wodna a Ochrona Wód, 19, Warszawa, IMGW, 1997 [In Polish].

13. CZARNECKA H. (Ed.) The Hydrological Atlas of Poland. IMGW, Wydawnictwa Geologiczne, Warszawa, 2005 [In Polish].

14. CHOIŃSKI A., PTAK M., STRZELCZAK A. Present-day evolution of coastal lakes based on the example of Jamno and Bukowo (the Southern Baltic coast). Oceanol Hydrobiol St 43, 2, 2014.

15. SIDLE R. C., ZIEGLER A. D., VOGLER J. B. Contemporary changes in open water surface area of Lake Inle, Myanmar. Sustain Sci 2, 1, 2007.

16. TAO S., FANG J., ZHAO X., ZHAO S., SHEN H., HU H., TANG Z., WANG Z., GUO Q. Rapid loss of lakes on the Mongolian Plateau. PNAS 112, 2015.

17. CHAUDHARY R., PILLAI R. S. Lake area change detection aided by GIS techniques: A study conducted at two Ramsar Sites of India. IJAES 5, 4, 2010.

18. BAI J., CHEN X., LI J., YANG L., FANG H. Changes in the area of inland lakes in arid regions of central Asia during the past 30 years. Environ Monit Assess 178, 1-4, 2011.

19. CHEN M., ROWLAND J. C., WILSON C. J., ALTMANN G. L., BRUMBY S. P. Temporal and spatial pattern of ther mokarst lake area changes at Yukon Flats. Alaska, Hydrol Process 28, 3, 2014.

20. YAO X., LIU S., LI L., SUN M., LUO J. Spatial-temporal characteristics of lake area variations in Hoh Xil region from 1970 to 2011. J Geogr Sci 24, 4, 2014.

21. MÎNDRESCU M., CRISTEA I. A., HUTCHINSON S. M. Bathymetric and sedimentological changes of glacial lake Ştiol, Rodna Masiff. Carpath J Earth Env 5, 1, 2010.

22. CEYLAN A., KARABORK H., EKIZOGLU I. An analysis of bathymetric changes in Altinapa reservoir. Carpath J Earth Env 6, 2, 2011.

23. YESUF H. M., ALAMIREW T., MELESSE A. M., ASSEN M. Bathymetric study of Lake Hayq, Ethiopia. Lakes Reserv
Res Manage 18, 2, 2013.

24. KUBINSKÝ D., LEHOTSKÝ M., WEIS K. Changes in bathymetry and land cover of riparian zone of an old artificial water reservoir vel'ký kolpašký. Carpath J Earth Env 9, 1, 2014.

25. TIBOR G., SADE R., HALL J. K., BEN-AVRAHAM Z., NISHRI A. Lake bathymetry and bottom morphology. Aquat Ecol 6, 2014.

26. MARSZELEWSKI W., ADAMCZYK A. Changes in the area of the Mazurian Lakes in the light of the cartographic materials at the scale 1:25000. Limnol. Rev. 4, 427, 2004.

27. GRADKE M. Changes in the Breńskie and Białe Miałkie lake area (Sławskie Lakeland) during the period 1778-2008. Stud Lim Tel 3, 1, 2009 [in Polish].

28. FABICH A., KWIDZIŃSKA M. Changes in the water surface area of Lakes Udzierz and Matasek in the light of cartographic materials. Limnol. Rev. 12, 4, 2012.

29. KUBIAK-WÓJCICKA K., LEWANDOWSKA I. Changes in the surface area of lakes in the Gwda River basin. Limnol. Rev. 14, 3, 2014.

30. ŁAWNICZAK A. E., KUTYŁA S., Lake-area changes in selected protected areas on the basis of cartographic materials. Prz. Geogr. 87, 1, 2015 [In Polish].

31. WIŚNIEWSKI B., WOLSKI T. Changes in Dąbie Lake bathymetry in the period 1962-1996. Limnol. Rev. 5, 2005.

32. PTAK M. Changes in the area and bathymetry of selected lakes of the Pomeranian Lake District, PG 133, 2013 [In Polish].

33. ŁAWNICZAK A. E., CHOIŃSKI A., KURZYCA I. Dynamics of lake morphometry and bathymetry in various hydrological conditions. Pol J Environ Stud 20, 4, 2011.

34. PTAK M. Lake evolution in the Żnin region in the years 1912- 1960 (central Poland), Quaest. Geogr. 32, 1, 2013.

35. CHOIŃSKI A., PTAK M. Lake infill as the main factor leading to lake's disappearance. Pol J Environ Stud 18, 3, 2009.

36. BONACCI O., POPOVSKA C., GESHOVSKA V. Analysis of transboundary Dojran Lake mean annual water level changes. Environ Earth Sci, 73, 2015.

37. KAISER K., HEINRICH I., HEINE I., NATKHIN M., DANNOWSKI R., LISCHEID G., SCHNEIDER T., HENKEL J., KÜSTER M., HEUSSNER K. U., BENS O., CHMIELESKI J. Multi-decadal lake-level dynamics in north-eastern Germany as derived by a combination of gauging, proxy-data and model ling. J Hydrol 529, 2015 [In Polish].

38. http://www.tutiempo.net/

39. Small Statistical Annual, GUS, Warszawa [In Polish].

40. WRZESIŃSKI D., CHOIŃSKI A., PTAK M. Effect of the North Atlantic Oscillation on the thermal characteristics of lakes in Poland. Acta Geophys. 63, 3, 2015.

41. KĘDZIORA A. Climate change and its impact on water conditions of the agricultural landscape. [In:] Cz. Koźmiński, B. Michalska, J. Leśny (Eds.) Climatic risk for agriculture in Poland. Wyd. Nauk. US, Szczecin, 2010.

42. CHMAL M. Methods of evaporation measurements from free water surface at meteorological station in Radzyn. Prz. Geof. 52, 3-4, 2008 [In Polish].

43. KANIECKI A. Influence of $\mathrm{XIX}^{\text {th }}$ centuries - the meliorations on change of level of waters. [In:] Choiński A. (Ed.) Influence of human impact on lake. UAM, PoznańBydgoszcz, 1997 [In Polish].

44. BABIŃSKI Z. Influence of land reclamation on the water surface of Lake Pniewite. [In:] Churski Z. (Ed.) Natural and anthropogenic changes in lakes and wetlands in Poland. UMK, Toruń, 1988 [In Polish].

45. PIEŃKOWSKI P., KUPIEC M. Process of overgrowing 
of Świdwie lake and changes in its surroundings land use from the beginning of the 19th century until the end of the 20th century. Zeszyty Naukowe. Inżynieria Środowiska/Politechnika Zielonogórska, 125, 2001 [In Polish].

46. PTAK M. Historical medium-scale maps as a source of information on the overgrowing of lakes. Limnol. Rev. 13, 3, 2013.

47. ŁAWNICZAK A. E. Overgrowing of two polymictic lakes in Central-Western Poland. Limnol. Rev. 3-4, 2010.

48. GRANÉLI W. Internal phosphorus loading in Lake Ringsjon, Hydrobiologia 404, 1999.

49. SOBCZYŃSKI T., JONIAK T. What threatens the ecosystem of Góreckie Lake in Wielkopolski National Park? [In:] B. Walna, L. Kaczmarek, M. Lorenc, R. Dondajewska (Eds.) Wielkopolski National Park in Natural Studies. Adam
Mickiewicz University in Poznan, Ecological Station in Jeziory, Poznań-Jeziory, , 2009 [In Polish].

50. KOWALCZEWSKA-MADURA K., GOŁDYN R., DONDAJEWSKA R. The bottom sediments of Lake Uzarzewskie - a phosphorus source or sink? Oceanol Hydrobiol St 39, 3, 2010.

51. PASZTALENIEC A., KUTYŁA S. The ecological status of lakes in national and landscape parks: Does the location of a lake and its catchment within a protected area matter? Pol J Environ Stud 24, 1, 2015.

52. PRZYBYŁEK J., NOWAK B. Impact of hydrogeological low flows and groundwater drainage by lignite open cast mine on aquifer systems of Gniezno Lakeland. Biul. Państw. Inst. Geol. 445, 2, 2011 [In Polish]. 